\title{
3 Haunted transitions: \\ Memory, theater, and gender discourse
}

\author{
Oana Popescu-Sandu
}

\begin{abstract}
"Behave right! Don't swear; Don't smoke ... . Don't eat with your elbows on the table ... . Don't chomp ... . Don't drink water during the main dish ... . Wash your underwear every night before you go to bed ... . We don't want your husband to think we're dirty" (Waxing West, Stănescu 2006, 50). This is part of the litany of advice that the Romanian mother, Marcela, gives to her West-bound daughter Daniela in Saviana Stănescu's English language play Waxing West (2006).This advice will prove to be unpractical. The new cultural and individual context in which the daughter, Daniela, finds herself in the US will require a different set of practical and performative gender behaviors in order for her life to function at a satisfactory level.

As the storyline goes, Daniela, a Romanian cosmetologist in her early thirties, goes to New York to marry Charlie Aronson, a software engineer in his late thirties. The marriage itself was engineered by their mothers, Marcela and Mrs. Aronson. In New York, Daniela finds out that Charlie is quite socially inept and not interested in the traditional marriage plot. As they negotiate their relationship, Daniela befriends Charlie's sister, Gloria, described in the stage directions as "late 40s, feminist visual artist," who overcomes her initial preconceived ideas about Daniela as a profiteering "gypsy." September 11, 2001 happens just as Daniela and Charlie are at a critical point in their relationship and Charlie is among those who disappear in the event. Throughout the play, as a Greek chorus, Stănescu inserts the vampire ghosts of Nicolae and Elena Ceauşescu, the former communist dictator and his wife. Initially, they appear during nightmares that Daniela starts having when she first decides to leave Romania. However, as the play advances they are present during most scenes. At the end of the play, Daniela fights away these ghosts, as well as the other characters who are literally pulling on her, to declare her independence from the past and from all those making demands of her: "I haven't done anything wrong. I don't owe anything to you ... . Rather I am owed some good normal boring times ... . Like everybody else ... . You ghosts have waxed the soul out of me. But you know what: there is still something left. A tiny piece of me. See?! I am hairy but not dead ..." (Waxing West, Stănescu 2006, 69). She tears up her return plane ticket to Romania and decides to start looking for Charlie.
\end{abstract}


At the beginning of the play Daniela relies on knowledge and gender discourses from Romania, her formative geographical and cultural space, in order to respond to encounters in her new home in New York. We learn from the play that she was of the generation of young people that actively participated in the 1989 events that led to the removal from power of the Ceauşescu regime. Her identity has been formed at the intersection of communism and post-communism. However, in spite of that initial act of agency, Daniela is now passive, caught between the communist past and the post-communist present as the political, economical, and social changes left her as a breadwinner for her family in Romania. She is stuck in a cosmetician job that covers their meals but does not allow her to fulfill herself. She also did not get a college education because, as she explains it, "it was the Revolution ... . The University Square ... . The new Elections ... . The meetings against corruption ... . Things were changing in Romania, I had to be there, didn't I? Didn't I?" (26). While she felt entitled to actively participate in the many social upheavals after 1989, Daniela also felt that her active participation provided her with a different kind of opportunities than she would get in a traditional college. Yet, as the post-communist transition moved along, she was left behind. The new social economy required the participants to compromise, something that she would not do, following in her father's footsteps.

Similarly, in New York, she finds that she is caught between Eastern European and American mores as she is trying to find an identity that will not lock her in gender and ethnic stereotypes but allow her to develop as an individual. The American characters whom she encounters are prey to preconceived ideas about Eastern Europeans, as well as caught in their own interrogation of the "American dream." Pre-existing labels - the mail bride, the feminist lesbian, the momma's boy, the homeless, the gypsy - are used by both groups, immigrants and locals, to stereotype and control the identity of the other. Consequently, previous experience, of those brought up in the West or the East, proves inadequate because it shapes standard responses to atypical situations. The characters are caught inside normative identities.

Therefore, this chapter argues that it is only when the characters can move into the space of a different discourse that they are ready to literally move out of their static and restrictive identities. In New York, Daniela will experiment and explore, push against the limits of her national and gender identity until she regains agency: "I can tell you something. I was strong. I made a decision. I did it MY way" (62). I will analyze this shift in identities in Waxing West by looking at three different aspects surrounding and/or shaping the play: the voice of the author, the storyline itself and its structure, and the way the storyline is facilitated by the dramatic genre.

I will use the concept of refraction to explain the way in which identity change is processed on each of these levels. I borrow the term refraction from David Damrosch who uses it to define the workings of world literature, a category to which Stănescu's play belongs. His phrase is "elliptical refraction," a process whereby works of literature are 
being received into the space of a foreign culture, a space defined in many ways by the host culture's national tradition and the present needs of its writers. Even a single work of world literature is the locus of a negotiation between two different cultures

(Damrosch 2003, 283)

The elliptical refraction is created by the back and forth circulation of the text between the originating and the receiving culture.

It is this negotiation of cultures that I am interested in and "refraction" is useful to analyze the process through which identity, memory, and cultures travel in the play and become part of the way in which an Eastern European writer understands her new American home and part of how Eastern European and American characters understand their world and each other. Temporal refraction is visible in the non-linear, non-chronological flashbacks traversing several geographical and ideological locations. Stănescu's play goes back and forth among scenes in 2000 and 2001 and to Daniela's memories of her participation in the events of 1989 . The non-linearity is necessary as characters engage in the process of remaking their identities and assessing the role of their past in their new self-narratives. Besides travelling in time, the narrative also travels in space, from Romania to New York. These multiple geographies imply multiple cultures and ways to perform identity. Finally, identity is processed not only in the plot but also inside the dramatic space itself. The stage and the dramatic form externalize the characters' inner conflicts. The stage and the stage directions help the audience and the reader visualize the simultaneous existence of past and present. The past - through the participation in the plot of the undead, the ghosts of the Ceaussescu couple-literally pulls on the character. These usually invisible non-corporeal entities actively participate in the plot and make specific physical and psychological demands from the body that they haunt.

\section{Identity and discourse crossing East/West}

The East/West dialogue is enabled by the process of refraction of the national space through the immigrant space: the national language and culture is refracted through the immigrant language and culture, and the Romanian communist past and post-communist present are seen through the lens of the American present. The characters survive their transitions and change their performative behaviors through this East/West dialogue that eventually creates fewer (or differently) traumatic mental and physical spaces that they can inhabit. This chapter argues that in Stănescu's play the process of refraction unsettles dominant and stereotypical discourses and identities creating a space for the characters' readjustment to their new realities and the possibility for them to inhabit a new, mutually constructed, cultural space.

By removing the characters from the national territory, physically and literarily, the play achieves a deeper focus on their personalities outside nationalistic 
motivations. Thus the play by Stănescu works as a double refraction. The characters are removed from the environment of strictly national literature by their author's immigration to a different space and a different literary language, with a different audience. Velibor Čolić, an immigrant Bosnian author, remarks in a keynote address on national literature that

National literature goes against world citizenship. In this "Weltanschauung," we wash our nation of all its sins, and turn it into a metaphor. Our homeland is no longer a country or a state, but often it is a pretty young woman who has been raped and tarnished; our nation is also the cemetery of our grandfathers, it is our religion, it is a white dove, or a mother.

(Čolić 2013)

National literature has the tendency to restrict characters to set functions and to idealize them. Characters removed from the idealizing tendency of national literature and also from the national space, outside of borders that prescribe discourse and behavior, are allowed the freedom to remake themselves and overcome their personal trauma.

Saviana Stănescu's play is definitely a text that travels. The play was written in New York, 10 years after the events of the Romanian Revolution, and in English - a triple distance from the original events in 1989, from the setting in Bucharest, Romania, and from Romanian, the primary language of the author. Stănescu settles into and interrogates her position as a Romanian-born author writing in English about post-communist realities in New York. This post-communist immigrant condition is also a concern of some of Stănescu's poetic works, inspired by her own immigrant experience.

In "Eurotic I (A Curriculum Vitae)" Stănescu plays upon linguistic themes to describe her identity as being "a breathing abbreviation of Romania" (Google Me!, 2006, 58) as well as "an abbreviation of the Balkans." She emphasizes:

I am a name, a number, a list.

A native, a woman, a foreigner,

A New-Yorker, a European, a Balkan-girl,

A GO-GO EAST, a GO-GO West

A poet, a playwright, a critic,

A teacher, a scholar,

A hi/story told by an idiot

Or a Nobel prize winner ...

She accentuates the multiplicity of positions created by immigration. She is "a New-Yorker, a European"-identities which are inflected positivelybut also "a Balkan-girl," exotic and childish. For some she is "a name, a number, a list," an impersonal statistic, while for others she is a multifaceted 


\section{Oana Popescu-Sandu}

professional. This openness that is potentially liberating can also be terrifying for those, like her character Daniela, not equipped to live transnationally.

Stănescu's poetic curriculum vitae is in contrast with Daniela's more prosaic self-introduction to the audience at the beginning of Waxing West: "I am Popescu Daniela, nationality: Romanian, age: 32, height: 165 centimeters, color of eyes: black, passport number 2670222, sex: female, tourist visa number: 555257, EXPIRED, accent: strong"(Waxing West, 2006, 5). Daniela describes herself in impersonal, official terms, but touching on the sense of danger implied in her immigrant situation. She contrasts who she is with who she should be: "I should be Daniela Aronson. ... . Nationality: American. Age: 27? Height ... 175. Color of eyes: blue!" (5). The dichotomy between who she is (Romanian, immigrant, average) and who she should be (American,younger, taller, blue-eyed) covers not only her legal status but also the norms of female beauty that she perceives to be more acceptable in her present context. This description comes right at the beginning of the play, a beginning which we later find out is actually the chronological end. Here Daniela breaks the fourth wall, addressing the audience directly: "You're not from the police, aren't you! Or from the INS? No, you don't look like ..." (5). The audience is the American audience, embodying danger and opportunity, crossing national and literary borders.

In the poem, Google Me!, Stănescu also approaches the individual role of her writing languages: "I had to move into another language/Mine was too small too poor too lazy/Too beautiful but self-destructive." She justifies her choice of English as a choice for a wider intelligibility: "That's why I really needed to move into the/English language/So people who google me can understand who I am/And what I am doing/On this noisy earth" (Google $M e !, 2006,9)$. This change is described spatially, as a physical move from the restrictive space of a minor language and culture, into the space of a major language and culture. However, there is no moving service that can help with this, each individual needs to travel alone: "I called the movers to help me/No one answered" (9).

Stănescu plays upon linguistic similarities to build a hybrid, linguistically refracted identity:

EU means I in Romanian.

$\mathrm{RO}$ is an abbreviation of Romania.

EURO might read as "I-an abbreviation of Romania".

$[\ldots]$

I invent words. I travel with my mind.

I am a VISAARTIST

VISA means TO DREAM in Romanian.

I cannot travel without a visa. I am afraid to go home to Romania.

What if I don't get my visa for America renewed? 
The poet relies on the fact that the reader knows EU means The European Union and that EURO is the European currency. She writes herself as a European citizen, belonging inside, rather than outside, of Europe. She linguistically rewrites her precarious status as an immigrant artist into a "dream artist." In spite of all of these connections, the textual play can be interrupted, and her reinvention of herself inside the text stopped, by her very immigrant condition which makes her depend on a document, a visa, that she herself cannot write or rewrite.

Moreover, her relationship with her native country is like a mania, as she writes in her poem "roMANIA" (Google Me!, Stănescu 2006). Her native culture acts like an extra skin, an inside that is outside, both self but also not self. It is an annoying layer that cannot be removed "like a hat glued to my brain/like a sweater made out of my skin/like a permanent tattoo on my left lung" (Google me!, Stănescu 2006, 67). She ends her poem strongly, with a demand: "please, leave me alone, Romania/I want to start/Living," a demand that is mirrored by Daniela at the end of Waxing West.

Stănescu's play seems to fit with other works in post-communist Romanian literature that place women at the center of the story and explore the different types of femininity present at the intersection of the two historical periods. One well-known example is the novel by Dan Lungu, Sunt o baba comunista [I am a communist hag], ${ }^{1}$ where, like in Waxing West, we see generations of Romanian women dealing more or less poorly with the post-communist condition and the encounter with the West. Romanian women have been plagued by the double burden during communism, free to find their place in the job market and build careers but also tied down by domestic obligations in a mostly patriarchal society. As Romanian feminist scholar Mihaela Miroiu points out

communism played a dual role for women: that of a supporter and that of an oppressor. The most positive aspects of the system were its support for child rearing as well as full access to education and employment, its apparently gender-neutral ideology, and its promotion of 'emancipation through work.

(Miroiu 2010, 576)

However, Miroiu emphasizes, this emancipation was accompanied by "an abolition of fundamental rights" (576) especially reproductive rights.

In the transition from communism to post-communism we also see changing views on stay-at-home women. In her research on the influence of communist gender policy on post-communist practices Denise Roman focuses on the fact that, during communism, women were legally bound to work and were not able to choose between the public job and remaining in the private sphere as homemakers (Roman 2002, 55). In the post-communist period, Roman adds, the rise of religious morality, the return to pre-modern village values focused on family and home, with an added layer of Western beauty stereotypes, accompanied by women's desire to withdraw from the public sphere created a 


\section{Oana Popescu-Sandu}

less friendly atmosphere for feminist work (56). However, because of a scarce job market many women were forced to stay in the public sphere and work in the low paying informal economy.

It is not that Daniela is not working in Romania. She does and she earns enough money to also help her family. What she seems to lack is more education and especially know-how on how to succeed in a post-communist society. In this respect she is more like her father, an idealist who protested against the communist regime and was forever branded because of that. Marcela's description of him ranges from idealism and nostalgia to ridicule, especially of his post-communist life:

All the smart guys in Romania, in Russia, in the whole Eastern Europe did what was to be done, robbed the damn dead socialist state, seized those ugly gray factories, buildings, lands, Ceauşescu's gold, something, everything, everybody with a tiny bit of brain stole what was to be stolen, and everything was to be stolen, in '90, in'91, even in '92, one could make a fortune in a blink, one smart enough to be in the right place at the right time and sign a damn piece of paper, 'this factory is mine,' 'those tons of oil are mine,' 'I'm the owner, I sell them to you,' to the foreigners, to the Americans, for dollars, REAL money, that's all, MONEY, privatizing yourself, bribing who was to be bribed, opening businesses! Everybody moved around but your father.

What Marcela captures here is the post-communist ethos in a nutshell: a lack of ethos actually and a rabid willingness to profit from what was perceived to be the carcass of the former communist state, a free-for-all, but only for those who were fast enough, savvy enough, and rich enough to profit. Marcela ridicules her husband's unwillingness to lie, to steal under the excuse that everybody was doing it, and sees his death from lung cancer as more like a betrayal and abandonment of his family in dire circumstances.

Marcela's reaction is further amplified by her frustration with the changing rules. She knew how to navigate communist society. She had the know-how to access the complicated relationship and favors exchange network necessary to obtain precious material goods. According to Daniela's description "Mom knew the right people. She got coffee, bonbons and vitamin C for us every month. I never thought about where those things came from" (12). Marcela is still willing to trade, but the market is more difficult for retirees like her. This time she will trade her own daughter in: "The luck-rain has come over Daniela. She is going to go to America and take all of us there!" (9). In her view Daniela is pretty but inconsequential, a slave, working in a beauty salon "waxing all those rich cows/who made illegal money after the Revolution" (8). So Marcela redirects her sense of agency into doing what any good mother would: arrange for the material welfare of her family through the marriage for Daniela who passively agrees to it. Marcela's position should not be read as heartless or cruel; her decision is shaped by years of struggle to gain the 
very material comforts that now Daniela has the chance to gain by agreeing to the performative act of the Western marriage. However, Charlie keeps postponing the marriage, and with it its potential benefits.

It is not surprising that in Stănescu's work the Western marriage is seen as a means to escape the post-communist condition and for "status exchange" (Levchenko and Solheim 2013, 31). Daniela is pushed by her mother to marry the American and redeem the family from their grey existence in Romania. The mother herself lost status with the transition from communism to postcommunism, so she sees this marriage as a way to recover status. However, the Western marriage makes the character face not only different gender predispositions existing in the target culture but also the immigrant condition. Among other things, according to Levchenko and Solheim, Romanian-born wives tend to earn less and be financially, legally, and socially dependent on their husbands (33), a situation in which Daniela finds herself.

Status exchange, in Daniela's case, is easier said than done, as different past "ghosts" haunt her. She can remove herself physically from the post-communist territory but not psychologically, and especially not from the terms of identity formation.Being tied to the patriarchal discourse of Romanian communism and post-communism, Daniela obeys her mother's wish to marry and leave but as soon as she does that she starts having nightmares inhabited by the Ceauşescu couple as ghostly vampires. The couple follows Daniela around, sarcastically comments on her life, looking for her weak spot that they intend to use to torment her. Here is the point where Daniela's character becomes a symptom of the ways in which a culture is affected by its past: Daniela stands as a representative of a whole generation of women and her identity as a symptom for the traumatic condition of transition.

This condition is characterized by the concurrent existence of multiple competing discourses about the past and the present. These discourses are fighting for ideological supremacy. As Lisa Wakamiya observes in her article "Post-Soviet Contexts and Trauma Studies," which discusses the connection between individual and cultural trauma:

The creation of an ambivalent postcommunist cultural trauma ... consists of the interaction of multiple discourses; it should be added that these discourses co-exist with others that may be equally vulnerable to integration within other ideologically determined discursive orders.

(Wakamiya 2011, 130)

In the case of Stănescu's work, the discourses in question are not only evolving national constructs but also international ones. The point of vulnerability still remains, as the immigrant's inner discourse might disappear in the new cultural and linguistic space in the the same way in which Daniela's identity disappears in post-communist Romania.

The play focuses on the discursive screens that the characters use in the process of adapting to their changing realities; these screens seem useless 
because they replicate obsolete social, national, and gender power/knowledge articulations (Foucault 1975). Daniela and her family see America through the preconceived ideas of the Eastern European looking West and through the material obsession of an impoverished post-communist population. Daniela's brother Elvis, so named because his mother was an Elvis fan, is unemployed and lazy, an example of failed masculinity. He is being supported financially by his mother and sister. Daniela pays for his tuition to get a degree in filmmaking but he does not attend his classes. The family has a calendar with American cars in their living room and Elvis watches Die Hard III: Die Hard with a Vengeance as the mother tries to clean up the apartment for the visit of Mrs. Aronson, Charlie's mother, who "had a Romanian cleaning lady for twenty years" and she "loves Romanians" (8). In Marcela's view:

[Daniela] will have EVERYTHING. Robots that clean the house for you. Machines that cook by themselves. Money that is invisible numbers on a small card like this. She won't have to worry about everything. She can have her mind scattered in the clouds forever: Of course she wants to go to America.

Daniela is not asked if she wants to marry or if she wants to go to America; from her mother's point of view the two are a given. Although Daniela insists on having Charlie visit her in Romania to get to know each other, her mother says no: "When you get a chance like this, you take it. You don't stop to ... 'try it on'. Look. Look how many others are in line" (21).

The fact that going to America is a highly desirable action and that this is a prevailing view is also emphasized by the amount of matrimonial or work offers from Romanian women of all ages that Marcela is asked to forward to America through Mrs. Aronson. The women write the ads with their idealized American suitors in mind: "nice, affectionate decent full-figured lady, mature, down-to-earth, poor but honest, wishes to meet financially stable generous successful gentleman, marriage-minded, athletic, well-educated, well-travelled, $\mathrm{D} / \mathrm{D}$ free, to share love's tender magic." The ad is a combination of idealism and idealization, of both the situation itself and of the people involved, as such ads usually are. Of course Marcela will not forward the letters. Her daughter does not need the competition (there is also a younger candidate with two college degrees) and she is guided by what she thinks is the American self-interest credo: "This is how people get rich there: they take care of each Mr. Green, they save every cent. There is no such thing as 'lend' if you don't get something in return" (22).

Daniela's own idea of what life will be in America is similarly idealized; however it is rendered less satirically by Stănescu:

maybe in that America ... it's a bit, just a bit, a tiny little bit, like in the movies. You have a nice house, two floors, four bedrooms, two cars, one 
for you, one for your husband ... breakfast and dinner with all the family ... . Three main courses. Two desserts! Everybody smiling! A coffee filter, a dishwashing machine, a microwave.

Along the lines of a dream of material prosperity provided by her mother, Daniela imagines the stereotypical American dream life, of a traditional stable family. Her vision mirrors Charlie's later explanation of what he dislikes in the same American dream.

Stănescu alternates Romanian scenes with American scenes so that the audience can see how the same reality is understood in each different context. In New York we see the feminist Gloria strongly objecting to her brother Charlie's marriage: "You accepted to get MARRIED in this ... odd! ... ancient! ... patriarchal, old-fashioned, disgusting way ... you don't need a female ... a pet from a Third World country" (23). She sees the marriage in stereotypical terms, only as a transaction buying and selling a female body. Gloria is less able to see the relationship as an exchange in which one party gets a comfortable life and the other gets a companion, and even less as a way to counter Charlie's known objections to the traditional marriage plot and provide for him a potentially meaningful relationship. The reason why Daniela was chosen is because she was perceived by Mrs. Aronson as more traditional, an alternative to the emancipated American Glorias, and also more exotic. Even more, her Eastern European whiteness is not marked racially, it makes her able to blend in and it "masks difference" (Robila in Levchenko and Solheimf 2013, 30).

Moreover, Gloria seems to ignore the limitation imposed on Daniela's actions by her status as a foreigner and an immigrant:

Forget this conventional stuff with marriage and all the bullshit around it. A woman has to be her own person. To make decisions for herself. Not to cook for some self-righteous prick who thinks he does her a big favor each time he penetrates her. Be a smart girl ... .

To "be smart" is the same advice given by Daniela's mother, the very reason why Daniela is in New York. However, the post-communist Romanian mother and the feminist American see the situation from completely different positions. In one definition, to be smart means to go through the Western marriage and gain all the imagined material and social advantages that come with that, while in the other it means to stay independent and explore the possibilities, including the sexual ones. Daniela seems to agree to enter a physical relationship with Gloria; however, she seems unable to follow through with her decision. Gloria reads this as Daniela's inability to choose for herself: "maybe you need your mom to tell you what to do, ask her for permission for ... everything!” (61) The play remains ambiguous as to what eventually 


\section{0}

\section{Oana Popescu-Sandu}

happened between the two. Daniels prompts the audience to "make up [its] own story" (62).

Moreover, Daniela dialogues with the audience and signals that she knows what her options are:

I can read in your eyes the questions-Why don't you change something? Go out! Get a job as a waitress or as a ... waitress, like so many illegal immigrants do. There are thousands of possibilities. You are in the city of all possibilities. Leave the jerk.

However, she rejects her narrow identification with the other "many illegal immigrants": "I don't want to be a waitress. I'm a cosmetologist. I have my own ... " (47). When she sees her identity refracted in the audience's eyes, Daniela is pushed to resist that label of "illegal immigrant."

Although Gloria is strong and independent as a woman, we find that Charlie is weak; he lived with his mother until the previous year, and did not recover after his former girlfriend left him for his sister. He will accept the bride delivered by his mother, together with his meals. Unfortunately, Mrs. Aronson suddenly dies soon after Daniela's arrival in the US so Daniela has to move in with Charlie. He no longer has a nagging motivator to actually marry Daniela so he keeps postponing the wedding. Charlie objects to being caught in the trappings of the American dream: "I didn't want all that shit: two-storey house, two cars, two kids, two dogs, weekends with the family. Fake communication. Fake smiles. Social convention ... a cheap Hollywood movie! ... I don't like being like everybody else" (63). Both Charlie and Daniela's visions are mediated and represented by making reference to film conventions, to "Hollywood" as a construct of what it means to be American.

Daniela's lack of familiarity with the American way of life is somehow matched by Charlie's who uses the stereotype of Hollywood to hide his own inability to fit in American society and live outside his mother's own vision of his own exceptionalism. We see here the almost verbatim contrast between Charlie's American dissatisfaction with the material accoutrements of middleclass life and the Eastern European's desire for the same things which were lacking during communism because of the socialist ideology and are still lacking in post-communism because of Daniela's inability to navigate the many levels of the capitalist and market economy.

The characters' discourse also evokes the stereotypes circulating between nationalities, ethnic groups, and East/West. Upset by his sister's invocation of the "third world pet," Charlie breaks into a litany of gender and ethnic stereotypes: "I don't need an American self-righteous woman. A Latino over-talkative chick. A British snobbish giraffe. A French sexy inflatable doll. An Asian midget/mistress" (24). However, he also does not know how to navigate this relationship that has been thrown on him and to which he agrees as passively as Daniela did. 
Charlie has his own problematic masculinity. As a child his passion was violin playing, a passion that his mother did not encourage for fear that he would become less of man: "You're great at violin, Charlie, but the violin is like a vampire, it softens you, it makes you suffer, squeak, and sob all day long. This is not a life for you, Charlie!" The American mother and the Romanian mother seem to share in the same desire to control and shape their children's life, especially in the conditions in which the children are made passive by their environments of lack or excess, respectively. This is why Mrs. Aronson described Charlie to his prospective wife as "kind smart sweet tender funny gentle well-behaved polite loving lovable SPECIAL" (64). However, in her anger, Daniela mocks that description and calls Charlie "a selfish ... robot" (64).

Daniela's dissatisfaction with Charlie is also sexual. He seems to enjoy sex only if he plays "the turkey game," a game intertwined with his American identity and indicating the prefabricated and precarious nature of that identity. In the stage directions Stănescu writes: "[Charlie] is in the turkey position behind an 'oven' built of a pile of shoeboxes or behind a transparent curtain. His head and his feet in white socks can be seen by the audience. Daniela has a knife in her right hand, pointed at Charlie." She threatens to eat the turkey and jab it with the knife and even cut off the turkey's genitalia until Charlie climaxes. In this game the power relationship is reversed. Daniela, the powerless female immigrant, has the power. However, Daniela resents the game and tries to introduce other, tamer, rituals to their physical relationship, attempts which fail. The last time they play this game Daniela gets angry and stabs Charlie forcefully with the plastic knife until she sees blood. This incident seems to mark a turning point in their relationship. Charlie announces that he will not engage in this role playing anymore. They both acknowledge the falsity of their situation.

While waiting for Charlie to decide on a date for their marriage, Daniela reflects on her condition and explores different avenues for her identity to take. She even consults the self-help books widely available on the American market. After she lists an endless numbers of titles she adds: "I'm afraid I'm still in the BEFORE stage. I still have emotions feelings confusion anger ... . Those AFTER people! They must be so happy. So peaceful. So empty ... OK!” (38). With the realization that all that "AFTER" stage is an illusion, Daniela addresses the audience directly in order to challenge their stereotypical view of Romania and the Balkans:

You don't have the references to our complicated Romanian Dacian Tracian Roman Ottoman Byzantine Balkan communist post-communist anti-communist pro-American history! All you know about us is Draculathe-vampire-, Ceauşescu-the-dictator and Nadia Comaneci-the-gymnast!

Daniela's list reveals the multilayered cultural identity that she belongs to, a construct which she is trying to deconstruct while at the same time engaging 
with her own misconceptions and those of her host culture. How can the selfhelp books be useful when they are completely oblivious to her own specific cultural trauma? She feels that all that the books achieve is loss of identity.

Daniela also befriends Uros, a fellow immigrant, who is, per stage directions, "a homeless Muslim Yugoslavian" in his late 50s. He lost his wife and child in the war in Yugoslavia and now his final dream is to go to Iraq and Syria and follow in the steps of the ancient hero Gilgamesh. He teaches Daniela how to steal books from Barnes and Noble for him, and convinces her to buy him a plane ticket with Charlie's money. When she goes to give Uros the ticket, she finds him dead. His death and inability to escape his condition and fulfill his dream makes her desperate and she reads that as a sign of her own inability to move ahead. She feels she cannot go back to Romania though, in spite of buying a ticket, because her mother has been spreading the story of her happiness to everybody. Uros's death is a symptom of his renunciation of the present and desire to retreat into his personal and the historical past.

\section{Of the undead}

The Ceauşescu couple appears early in Stănescu's play in a section that is labeled "The First Nightmare." Returned from a "busy tooth-in-neck nightlife" as vampires in the Middle East and New York, the Ceaussescus miss home and, in the nightmare, are visiting their burial plots in a Bucharest cemetery. There Daniela speaks again to the audience to tell us how her father was persecuted and imprisoned for being critical of the regime. The vampires make fun of her and her attachment to her father when he, Ceauşescu, was supposed to be the father of the nation. They postpone "eating" her while they search for her "weak-spot-of-the-first-degree" which they will use to psychologically and physically torment her. That weak spot will turn out to be Daniela's new-found feelings for Charlie.

The presence of the Ceauşescu couple is not only an occurrence of Daniela's personal, individual trauma, but also the signal of a collective historical trauma. Daniela probably has never met the Ceauşescus, but her personal history is used dramatically to illustrate the collective traumatic content. The image of the Ceauşescu couple is displaced, removed from its initial context, but it is an image, however distorted, that travelled with Daniela's memory and was refracted, filtered, through her imaginary, even when she reached the US. Ironically, it is in the US that this image connects with another popular culture topos concerning Romania: that of the vampire originating in Bram Stoker's novel Dracula. Part of this might also be a remnant of communist propaganda that described the "enemies of the people" as those who were "sucking the blood of the people" [sug single poporului]. ${ }^{2}$ As the tables were reversed and now the First Couple is the enemy of the people, it might seem only natural that they are now "feeding", if only symbolically, on the blood of the people.

The Ceauşescus' presence is haunting the stage as they are also haunting history. They become a topos that gains its energy from people's insecurities 
and the fact that post-communist society Romanian has not fully reconciled with its past. The Ceaussescu's death itself also contributes to the narrative that makes them perfect candidates for a ghost-like existence as their execution and speedy secret burial had nothing of the ritualistic qualities necessary to put souls "at rest." So their presence on the stage is a cultural hybrid, a collage of imaginaries, of psychological and cultural elements.

The omnipresence of the ghost is also enabled by Stănescu's use of the stage. In the stage direction she indicates that throughout the play "the actors are lined up, upstage, hidden in the semi-darkness. They may be present on the stage at all times, body-reacting to Daniela's actions/words." This simultaneous presence of characters who belong, narratively, to multiple times, spaces, and cultures provokes a sense that the time/space/culture differentiations have collapsed and that multiple discourses occupy the same space at the same time. Daniela seems to feel the presence of these characters and in a scene close to the end of the play they all come to the foreground pushing and pulling on her and speaking simultaneously. The Ceauşescus and the other Romanian characters are reliving the dictators' escape from Bucharest while Daniela and the American characters are enacting 9/11. Daniela inhabits both realities at once, which suggests the traumatic quality of both:

Daniela: One cannot escape.

Gloria: One can escape.

Marcela: My son-in-law is a businessman! In New York!

Gloria: The towers.

Daniela: The walls.

Elvis: The dreams.

Ceauşescu: The Golden Dream of communism!

Gloria: Burning. Melting.

Daniela: Crumbling.

Elvis: Watching on TV.

Marcela: A nightmare.

Gloria: A choreography of death.

Daniela: One cannot escape. Pain speaks all languages.

[At this point all characters suggest to Charlie and Daniel to run.]

Here discourse breaks into few or one-word sentences that could describe both realities. It is while inhabiting this traumatic landscape, where the Romanian 1989 events are refracted through the trauma of the American 9/11, that Daniela decides to stop and choose her own reality. That reality is anchored on her hearing the sound of Charlie's violin. This is her weakest point: her new feelings for Charlie, her new understanding of him which, unfortunately, happens at the moment of his disappearance: "I can hear! I can hear you playing the violin, Charlie ... . You will come home. You will find me here. We'll talk. And I won't say, 'I'm sorry.' I'll say, 'Let's start again!' (70). 
In the last scene of the play entitled END/BEGINNING there is no indication of the presence of any other characters. There is only Daniela who shows the audience Charlie's photo and asks if they have seen him. She enters the discourse of 9/11 families, searching for their loved ones, a discourse that seems to ground her and silence all the others.

\section{Conclusions: East-West}

At the meeting point of Eastern European and Western women characters, opinions and positions change. Western women are changing in response to understanding the motivations behind a different kind of femininity. Their preconceived ideas are developing into more compassionate forms of communication. At first Gloria sees Daniela as an exotic childish foreigner who needs guidance ("Even a word like 'conventional' sounds sexy coming out of your mouth" says Gloria), but this view changes into that of a woman whom Gloria befriends and with whom she shares feminine rituals. For Daniela, Gloria is an example of alternate femininity that encourages her to make her own choices. This mutual transformation is an evolution in the relationship between East and West which used to be one of superior-inferior, civilized-uncivilized, rich-poor, etc.

At the end of Stănescu's play Daniela physically pushes away all characters pulling her in different directions and proclaims her break from the past: "I haven't done anything wrong. I don't owe anything to you ... . You ghosts have waxed the soul out of me. But you know there's still something left." Looking for Charlie after 9/11, she describes him in his words, using Charlie's own description of himself, the one that she disliked earlier. This is a sign that she has reached a deeper understanding of Charlie's identity, an understanding based on compassion.

The end of the play is the beginning of some sort of freedom for Daniela. She has decided to stay, to acknowledge her belonging to the American space and also to give up being split between her multiple cultural identities. This project might be an impossibility. We know because we have already heard her self-description at the beginning of the play but at least it marks the end of an open conflict among the warring sides of Daniela's past and present and a possibility to move towards a future. As Stănescu writes, Romania may be "like a permanent tattoo/on [her] left lung/like a hi/story written/in [her] DNA/like a rubber doll/inflated by the memory of [her] childhood" but at least a declaration of freedom has been made and the haunting has stopped.

\section{Notes}

1 In 2013 the novel was adapted into a movie of the same name directed by Stere Gulea.

2 The image of the vampire politician is also used by the canonical Romanian playwright I.L. Caragiale (1884) at the very beginning of his comedy $O$ scrisoare pierduta [A Lost Letter]. 


\section{Bibliography}

Caragiale, Ioan Luca. O Scrisoare pierduta, 1884. Accessed 15 May 2014. http://regi zorcautpiesa.ro/piese-de-teatru-online/O-scrisoare-pierduta-1412-1256.html.

Colić, Velibor. "The Warriors' Cry—Nationalist Literature. Keynote Address," Edinburgh World Writers Conference, 2013. www.edinburghworldwritersconference.org (accessed November 2, 2013).

Damrosch, David. What is World Literature. Princeton, NJ: Princeton University Press, 2003.

Foucault, Michel. Discipline and Punish: The Birth of the Prison. New York: Vintage Books, 1975, 1995.

Levchenko, Polina and Catherine Solheim. "International Marriages Between Eastern European-Born Women and U.S.-Born Men.” Family Relations 62, no. 1 (February 2013): $30-41$.

Miroiu, Mihaela. “'Not the Right Moment!' Women and the Politics of Endless Delay in Romania." Women's History Review 19, no. 4 (2010): 575-93.

Roman, Denise. "Gendering Eastern Europe: Pre-feminism, Prejudice, and East-West Dialogues in Post-Communist Romania." Women's International Forum 24, no. 1 (2002): 53-66.

Stănescu, Saviana. Google Me! Bucharest: Vinea Press, 2006.

-Waxing West." In Global Foreigners. An Anthology of Plays, by Carol Martin and Saviana Stanescu, 1-70. London: Seagull Books, 2006.

Wakamiya, Lisa Ryoko. "Post-Soviet Contexts and Trauma Studies."“ Slavonica 17, no. 2 (November 2011): 133-44. 